\title{
$\mu$-Opioid Receptor Desensitization in Mature Rat Neurons: Lack of Interaction between DAMGO and Morphine
}

\author{
Christopher P. Bailey, Daniel Couch, Elizabeth Johnson, Katie Griffiths, Eamonn Kelly, and Graeme Henderson \\ Department of Pharmacology, University of Bristol, School of Medical Sciences, Bristol BS8 1TD, United Kingdom
}

$\mu$-Opioid receptors (MORs) exhibit rapid desensitization and internalization during exposure to various opioid agonists. In some studies, however, morphine has been observed to produce little MOR desensitization or internalization. We examined desensitization in mature rat locus ceruleus (LC) neurons and confirmed that morphine is a very poor desensitizing agent, whereas $\left[\mathrm{D}-\mathrm{Ala}^{2}, \mathrm{~N}-\mathrm{MePhe}{ }^{4}, \mathrm{Gly}-\right.$ $\mathrm{ol}^{5}$ ]enkephalin (DAMGO), a high-efficacy agonist, and methadone, an agonist we observed to be of equivalent efficacy to morphine, produced profound rapid desensitization. Similarly, by measuring plasma membrane receptor levels in HEK293 cells stably expressing T7-epitope-tagged rat MOR1 at near physiological levels (HEK293-MOR1 cells), DAMG0 and methadone but not morphine caused rapid MOR internalization. It has been reported that a low concentration of DAMGO, coapplied with morphine, caused morphine to induce MOR internalization. We examined whether this interaction occurred in mature mammalian neurons at the level of receptor desensitization. Coapplication of low concentrations of DAMGO did not increase morphine-induced desensitization in LC neurons but caused a lesser degree of desensitization than DAMGO alone. We also failed to observe an enhancement by DAMGO of morphine-induced desensitization in the electrically stimulated guinea pig ileum myenteric plexus-longitudinal muscle preparation. In HEK293-MOR1 cells, low concentrations of DAMGO did not convert morphine into a receptor-internalizing agent. The data presented here fail to support the theory that low concentrations of DAMGO can increase morphine-induced MOR desensitization or internalization.

Key words: desensitization; opiate (morphine); opioid; internalization; locus ceruleus; oligomerization

\section{Introduction}

The prototypic $\mu$-opioid agonist morphine, unlike $\left[\mathrm{D}-\mathrm{Ala}^{2}, N\right.$ $\mathrm{MePhe}^{4}, \mathrm{Gly}^{-\mathrm{ol}^{5}}$ ] enkephalin (DAMGO) and methadone, induces little $\mu$-opioid receptor (MOR) internalization (Arden et al., 1995; Keith et al., 1996; Whistler et al., 1999; Alvarez et al., 2002; Borgland et al., 2003). The reason for this is currently not known, and there is confusion as to whether this is simply attributable to the relatively low agonist efficacy of morphine. Whistler et al. (1999) reported morphine and DAMGO as having higher efficacy than methadone in HEK293 cells, whereas Alvarez et al. (2002) and Borgland et al. (2003) reported that morphine had equivalent or lower efficacy than methadone in other cell types. In contrast to rapid receptor internalization, there is controversy regarding the ability of morphine to induce rapid receptor desensitization, because Alvarez et al. (2002) saw little morphineinduced, but robust methadone-induced, desensitization in rat locus ceruleus (LC) neurons, whereas Borgland et al. (2003) observed both methadone- and morphine-induced desensitization in AtT20 cells.

A recent paper examining MOR internalization in HEK293 cells demonstrated rapid receptor internalization when a low concentration of the high-efficacy agonist DAMGO was coapplied with a saturating concentration of morphine (He et al.,

\footnotetext{
Received June 25, 2003; revised Sept. 29, 2003; accepted Sept. 29, 2003. This work was supported by the Wellcome Trust.

Correspondence should be addressed to Christopher P. Bailey, Department of Pharmacology, University of Bristol, School of Medical Sciences, University Walk, Bristol BS8 1TD, UK. E-mail: chris.bailey@bris.ac.uk. Copyright $\odot 2003$ Society for Neuroscience $\quad$ 0270-6474/03/2310515-06\$15.00/0
}

2002). Thus, DAMGO appeared to convert morphine into an internalizing agent. This effect was attributed to the fact that MORs existed as homo-oligomers and that DAMGO, by binding to some receptors in the oligomeric assembly while morphine is bound to the remainder, could convert morphine into a receptorinternalizing agonist. Coadministration of low concentrations of DAMGO with morphine was also reported to reduce tolerance to morphine analgesia, confirming the potential physiological significance and therapeutic potential of this interaction.

In the present study, we sought to determine whether the phenomenon of DAMGO enhancing morphine-induced MOR desensitization occurs in mature mammalian neurons. The brainstem nucleus LC contains a relatively homogenous population of noradrenergic neurons that express MORs but not $\delta$-opioid (DOR) or $\kappa$-opioid receptors (Pepper and Henderson, 1980). MORs in LC neurons are coupled to inwardly rectifying potassium channels. The current through these channels provides a real-time read out of receptor activation and is therefore ideal for the study of receptor desensitization. We also examined opioid-induced inhibition of nerve-evoked contractions of the guinea pig ileum myenteric plexus-longitudinal muscle preparation (GPILM-MP). The data we present provides evidence that morphine and methadone are partial agonists of equivalent efficacy and that morphine, unlike DAMGO or methadone, causes negligible desensitization. However, morphine cannot be converted into a desensitization-producing agonist by coapplication of low concentrations of DAMGO. In fact, morphine inhibits DAMGO-induced desensitization. Additional experiments ex- 
amining MOR loss from the plasma membrane in HEK293 cells stably expressing T7-epitope-tagged rat MOR 1 at near physiological levels (HEK293-MOR1 cells) provide additional evidence that morphine is a poor MOR internalizing agonist but similarly fail to demonstrate a functional interaction with DAMGO.

\section{Materials and Methods}

Slice preparation. Brainstem slice preparation was adapted from that described by Ishimatsu and Williams (1996). Male Wistar rats (130-170 $\mathrm{gm}$ ) were killed by cervical dislocation, and the brains were removed and rapidly submerged in ice-cold cutting solution containing the following (in mM): $20 \mathrm{NaCl}, 2.5 \mathrm{KCl}, 0.5 \mathrm{CaCl}_{2}, 7 \mathrm{MgCl}_{2}, 1.25 \mathrm{NaH}_{2} \mathrm{PO}_{4}, 85 \mathrm{su}-$ crose, $25 \mathrm{D}$-glucose, and $60 \mathrm{NaHCO}_{3}$ (saturated with $95 \% \mathrm{O}_{2}-5 \% \mathrm{CO}_{2}$ ). Horizontal slices ( $250 \mu \mathrm{m}$ thick) containing the LC were prepared using a vibratome (Agar Scientific, Stansted, UK). Immediately after cutting, slices were submerged in an artificial CSF ( $\mathrm{aCSF}$ ) [containing the following (in mM): $126 \mathrm{NaCl}, 2.5 \mathrm{KCl}, 1.2 \mathrm{MgCl}_{2}, 2.4 \mathrm{CaCl}_{2}, 1.2 \mathrm{NaH}_{2} \mathrm{PO}_{4}, 11.1$ D-glucose, $21.4 \mathrm{NaHCO}_{3}$, and 0.1 ascorbic acid (saturated with $95 \%$ $\mathrm{O}_{2}-5 \% \mathrm{CO}_{2}$ at $34^{\circ} \mathrm{C}$ ) ] and were left to equilibrate for at least $1 \mathrm{hr}$ before recordings were made.

Whole-cell patch-clamp recordings. Slices were submerged in a slice chamber $(0.5 \mathrm{ml})$ and superfused $(2.5-3 \mathrm{ml} / \mathrm{min})$ with aCSF at $33-34^{\circ} \mathrm{C}$. LC neurons were visualized by Nomarski optics, and individual cell somata were cleaned by gentle flow of aCSF from a pipette. Whole-cell voltage-clamp recordings $\left(V_{h}\right.$ of $-60 \mathrm{mV}$ ) were made using electrodes (3-6 M $\Omega$ ) filled with the following (in mM): $115 \mathrm{~K}$-gluconate, $10 \mathrm{HEPES}$, 11 EGTA, $2 \mathrm{MgCl}_{2}, 10 \mathrm{NaCl}, 2 \mathrm{MgATP}$, and $0.25 \mathrm{Na}_{2} \mathrm{GTP}, \mathrm{pH} 7.3$ (270 mOsm). Recordings were filtered at $2 \mathrm{kHz}$ using an Axopatch 200B amplifier (Axon Instruments, Foster City, CA) and displayed on a chart recorder (Gould Instruments, Loughton, UK). All drugs were applied in the superfusing solution. Naloxone $(1 \mu \mathrm{M})$ was applied at the end of each agonist application to antagonize the response completely. Desensitization of the MOR response was quantified by expressing the magnitude of decline in current from its peak, as a percentage of the initial peak current.

GPILM-MP preparation. Male guinea pigs (250-500 gm) were killed by cervical dislocation. GPILM-MP preparations were prepared according to the method of Kosterlitz et al. (1970). The tissue was mounted in a $3 \mathrm{ml}$ organ bath under $1 \mathrm{gm}$ tension at $37^{\circ} \mathrm{C}$ and stimulated at $0.1 \mathrm{~Hz}$ with rectangular electrical pulses of $500 \mathrm{msec}$ duration and supramaximal current. The resulting contractions were recorded isometrically on a chart recorder (Graphtec, Irvine, CA). The bathing fluid contained the following (in mM): $118 \mathrm{NaCl}, 4.75 \mathrm{KCl}, 2.54 \mathrm{CaCl}_{2}, 1.19 \mathrm{MgSO}_{4}, 24$ $\mathrm{NaHCO}_{3}, 0.93 \mathrm{KH}_{2} \mathrm{PO}_{4}$, and 11 glucose (saturated with $95 \% \mathrm{O}_{2}-5 \%$ $\mathrm{CO}_{2}$ ).

All use of animals was in accordance with the UK Animals (Scientific Procedures) Act 1986.

MOR internalization in stable HEK293-MOR cell lines. T7-epitopetagged rat MOR1 and MOR1B constructs were stably expressed in HEK293 cells using Lipofectamine (Invitrogen, Paisley, UK) transfection. MOR internalization was measured by ELISA using a colorimetric alkaline phosphatase assay, as described by Daunt et al. (1997). Briefly, cells were exposed to agonist for various periods of time before fixation in $3.7 \%$ paraformaldehyde for $5 \mathrm{~min}$. This fixation protocol results in minimal permeabilization of the plasma membrane (Daunt et al., 1997). Fixed cells were then incubated with primary antibody (anti-T7 monoclonal, at 1:5000; Novagen, Madison, WI). Cells were washed and incubated with secondary antibody (goat anti-mouse conjugated with alkaline phosphatase; 1:1000), a colorimetric alkaline phosphatase substrate (Bio-Rad, Hercules, CA) was added, and samples were assayed at $405 \mathrm{~nm}$ with a microplate reader. Using this method, only plasma membrane receptors were bound by antibody, as confirmed by single-cell imaging experiments. Background was subtracted by simultaneous assay of untransfected HEK293 cells. Percentage surface receptor loss was calculated by normalizing data from each treatment group to corresponding control surface receptor levels determined from cells not exposed to opioid agonists. All experiments were performed in triplicate.

Materials and statistical analyses. All reagents were purchased from
Sigma (Poole, UK), except $\left[\mathrm{Met}^{5}\right]$-enkephalin (ME) (Bachem, St. Helens, UK) or when indicated. MOR1 and MOR1B constructs were kind gifts from Prof. Volker Höllt (Otto-von-Guericke University, Magdeburg, Germany). All data are expressed as means \pm SEMs. Unpaired, two-tailed Student's $t$ test was used to assess statistical significance.

\section{Results \\ Morphine induced much less rapid desensitization than DAMGO or methadone in LC neurons}

With receptor-saturating concentrations of DAMGO $(10 \mu \mathrm{M})$ or methadone $(30 \mu \mathrm{M})$, the amplitude of the evoked current decayed in the continued presence of the drug (Fig. 1). The time course of desensitization could be fitted to a single-exponential decay (Fig. $1 B$ ), and, although the rate of DAMGO-induced desensitization was faster than that of methadone, both the extrapolated plateau current levels and empirical values calculated after $30 \mathrm{~min}$ of drug exposure were identical (Fig. 1C-E). Morphine, however, caused very little desensitization. The peak currents evoked by maximally effective concentrations of DAMGO (10 $\mu \mathrm{M})$, methadone $(30 \mu \mathrm{M})$, and morphine $(30 \mu \mathrm{M})$ were $101.0 \pm$ $4.9 \%(n=4), 65.8 \pm 5.0 \%(n=4)$, and $66.8 \pm 3.4 \%(n=5)$, respectively, of that evoked by a maximal concentration of $\mathrm{ME}$ $(10 \mu \mathrm{M})$, confirming that methadone and morphine are partial agonists of equivalent efficacy. Given the slightly slower onset of the methadone response (Fig. $1 A$ ), during which some desensitization may be occurring, it is possible that methadone has just slightly greater efficacy than morphine. The responses evoked by DAMGO, methadone, and morphine took a considerable time to reverse on washout of the drug, whereas ME-evoked currents reversed rapidly. MOR desensitization induced by ME $(30 \mu \mathrm{M})$ was homologous with respect to the current evoked through $\alpha_{2}$ adrenoceptors and was reversible within $1 \mathrm{hr}$ (data not shown).

\section{DAMGO did not enhance morphine-induced desensitization in LC neurons}

We exposed LC neurons to either 100 nM DAMGO or $100 \mathrm{~nm}$ DAMGO plus $5 \mu \mathrm{M}$ morphine (Fig. 2). Contrary to DAMGO converting morphine into a desensitizing agent, less desensitization was observed when DAMGO and morphine were coapplied (Fig. 2A,B). This is perhaps to be expected because, at these concentrations, when DAMGO and morphine are combined, the majority of receptors will be occupied by morphine. Initially, 5 $\mu \mathrm{M}$ morphine and $100 \mathrm{~nm}$ DAMGO were studied because these were the concentrations used by He et al. (2002), who deemed 5 $\mu \mathrm{M}$ morphine to be a receptor-saturating concentration. In our experiments, $5 \mu \mathrm{M}$ morphine evoked a response that was only $89 \pm 4.5 \%$ of maximum, whereas $30 \mu \mathrm{M}$ evoked a maximal response. We therefore repeated the experiment examining the DAMGO-morphine interaction with $30 \mu \mathrm{M}$ morphine and raised the concentration of DAMGO to $500 \mathrm{nM}$ to maintain the same level of receptor occupancy by DAMGO (calculated using $K_{\mathrm{d}}$ values of $0.6 \mu \mathrm{M}$ for morphine and $0.3 \mu \mathrm{M}$ for DAMGO; C. P. Bailey and G. Henderson, unpublished data). Figure $2 C$ illustrates that, even at these concentrations, morphine was not a desensitizing agent when coapplied with DAMGO. Indeed, as above, combined administration of DAMGO and morphine resulted in less desensitization than DAMGO alone.

\section{DAMGO did not induce morphine desensitization in the GPILM-MP preparation}

We next examined the possible synergy between DAMGO and morphine by measuring desensitization of agonist-evoked inhibition of electrical twitch in the GPILM-MP preparation. Because 


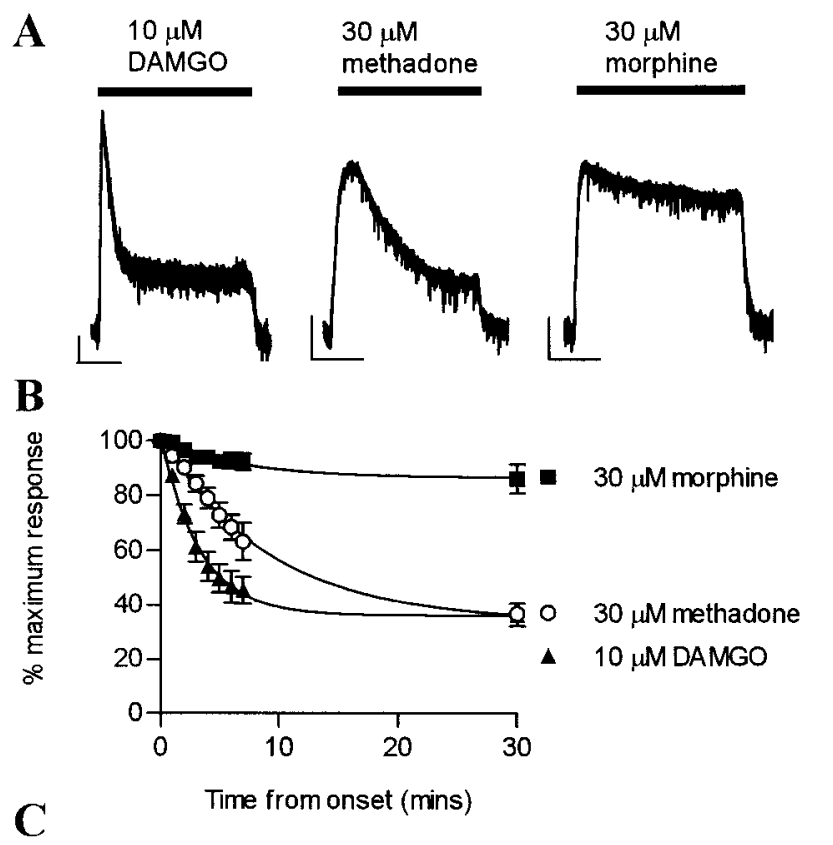

\begin{tabular}{|l|c|c|}
\hline & $\begin{array}{c}t_{1 / 2} \text { best fit } \\
(95 \% \text { confidence } \\
\text { intervals })\end{array}$ & $\begin{array}{c}\text { Plateau best fit (\% } \\
\text { of max response } \pm \\
\text { standard error) }\end{array}$ \\
\hline $10 \mu \mathrm{M}$ DAMGO & $2.3 \operatorname{mins}(2.0-2.7)$ & $36.2 \pm 1.6 \%$ \\
\hline $30 \mu \mathrm{M}$ methadone & $6.3 \operatorname{mins}(5.4-7.7)^{\star}$ & $33.9 \pm 2.1 \%$ \\
\hline $30 \mu \mathrm{M}$ morphine & $4.8 \operatorname{mins}(3.0-10.9)^{\star}$ & $86.2 \pm 1.7 \%^{\dagger}$ \\
\hline
\end{tabular}
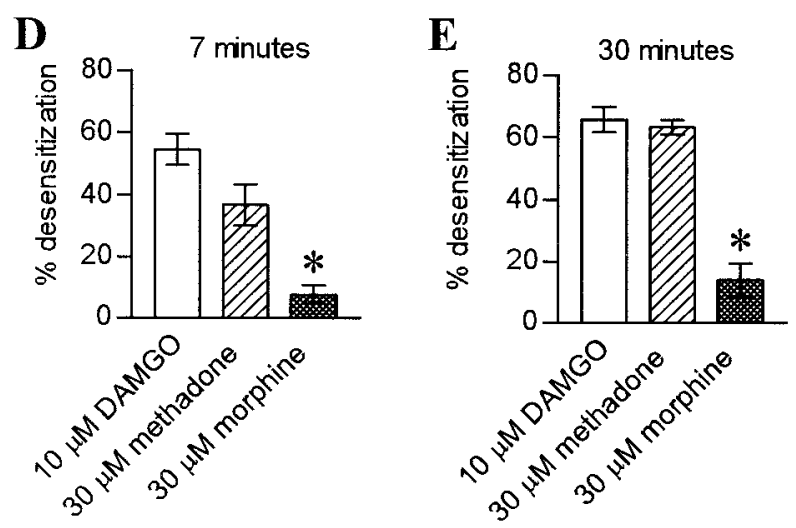

Figure 1. DAMG0 and methadone produced greater rapid desensitization than morphine in $\mathrm{LC}$ neurons. $A$, Whole-cell patch-clamp recordings from three individual $\mathrm{LC}$ neurons. Calibration: $50 \mathrm{pA}, 10 \mathrm{~min}$. DAMGO $(10 \mu \mathrm{m})$ and methadone $(30 \mu \mathrm{m})$, but not morphine $(30 \mu \mathrm{m})$, induced rapid desensitization. $B$, Rate of decay of responses. Pooled data of percentage maximum response plotted against time after maximum response was attained ( $n=4$ for DAMGO and methadone; $n=4-13$ for morphine). Data were fitted to a single exponential ( $r^{2}>0.999 \mathrm{for}$ each). C, Table summarizing kinetics of desensitization ( $n$ values as in $B ;{ }^{*} p<0.05$ vs DAMG0; ${ }^{\dagger} p<0.05$ vs DAMGO or methadone). $D, E$, Percentage desensitization at 7 and 30 min after peak. Morphine induced less desensitization than DAMG0 or methadone $\left({ }^{*} p<0.05\right.$ morphine vs methadone or DAMG0; $n=4-13$ for morphine; $n=4$ for DAMG0 and methadone).

$5 \mu \mathrm{M}$ morphine produced complete inhibition of the twitch, we initially chose to use a submaximal concentration of morphine ( 1 $\mu \mathrm{M})$. We saw no significant desensitization to morphine or DAMGO (100 nM) either alone or when added in combination (Fig. 2D). We then increased the concentration of morphine to $30 \mu \mathrm{M}$ and again failed to observe induction of desensitization when it was applied along with DAMGO (data not shown).
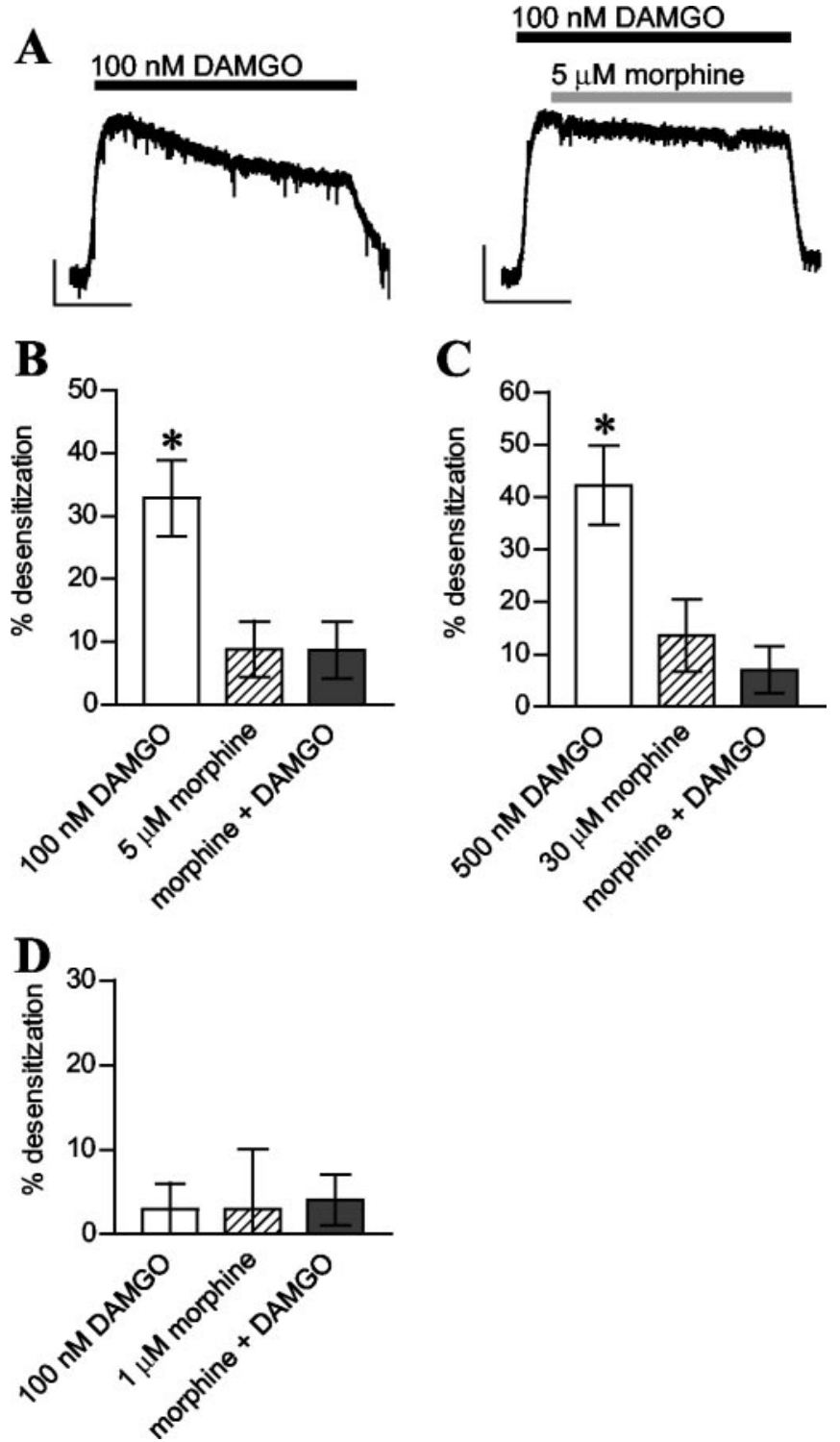

Figure 2. DAMGO coapplied with morphine did not induce MOR desensitization. $A-C$, Data from $\mathrm{LC}$ neurons. $A$, Representative current traces from two $\mathrm{LC}$ neurons. Calibration: $100 \mathrm{pA}, 10$ $\mathrm{min})$. B, MOR desensitization induced by DAMGO (100 nM) was inhibited by morphine $(5 \mu \mathrm{M})$. Pooled data $(n=4-7)$ taken 30 min after peak response. DAMG0 alone induced more desensitization than morphine alone or morphine plus DAMGO ( ${ }^{*} p<0.05$ for both). C, Desensitization induced by morphine $(30 \mu \mathrm{M})$ was not increased by coadministration with DAMGO $(500 \mathrm{nM})$ $\left({ }^{*} p<0.05\right.$ DAMGO vs morphine or morphine plus DAMG0; $\left.n=4\right)$. D, DAMGO did not reveal morphine as a desensitizing agent in GPILM-MP preparations. Pooled data $(n=3)$ showing percentage desensitization after $15 \mathrm{~min}$ of drug exposure.

\section{DAMGO did not convert morphine into a MOR internalizing} agent in HEK293 cells

Because morphine was not converted into a desensitizationinducing agonist by low concentrations of DAMGO in either LC neurons or the GPILM-MP preparation, we next examined whether DAMGO could enhance morphine-induced surface MOR loss in HEK293 cells. To mimic the physiological situation, we studied surface-receptor loss as opposed to internalization, and the cell line we used had a near physiological MOR1 expression level $\left(174.8 \pm 27.6 \mathrm{fmol} / \mathrm{mg}\right.$ tissue, as assessed by $\left[{ }^{3} \mathrm{H}\right] \mathrm{di}-$ prenorphine saturation binding compared with rat LC expression levels, $92.2 \pm 7.0 \mathrm{fmol} / \mathrm{mg}$ ) (Tempel and Zukin, 1987).

A saturating concentration of morphine $(30 \mu \mathrm{M})$ caused sig- 
A

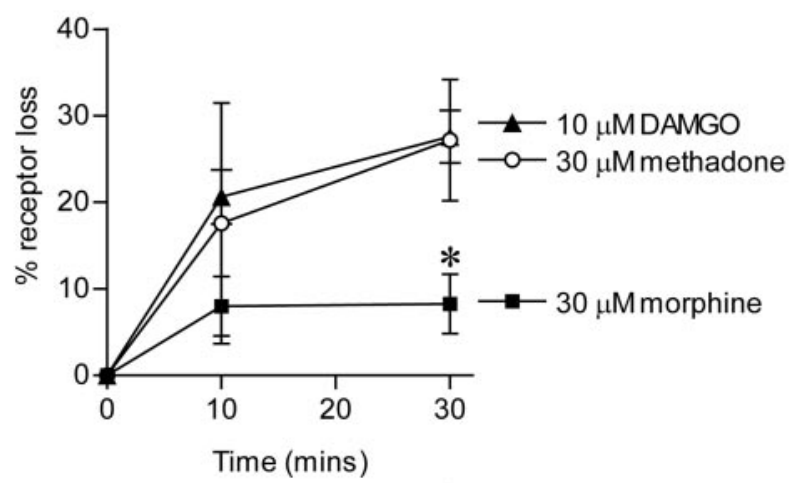

B

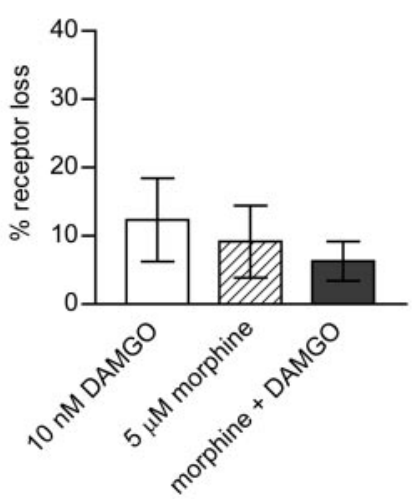

D

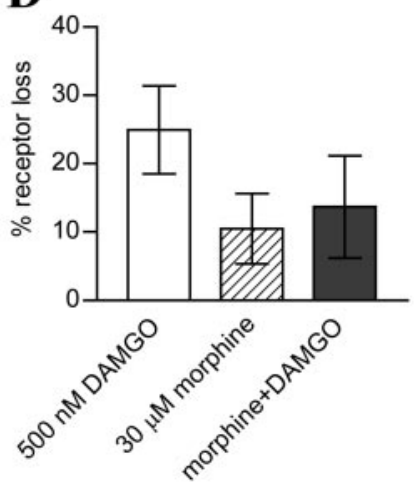

C

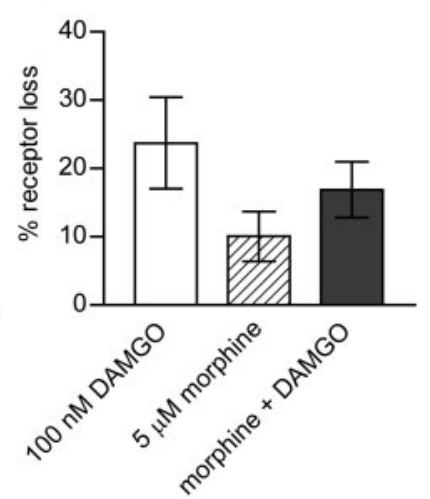

$\mathbf{E}$

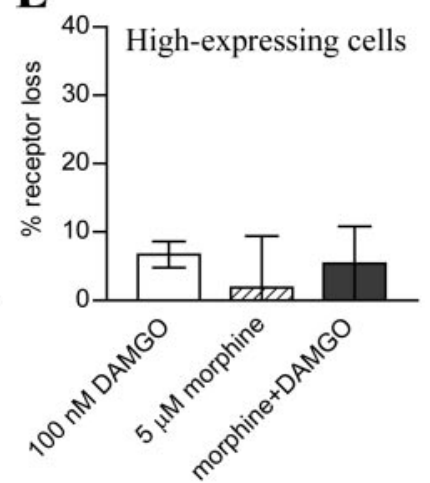

Figure 3. DAMGO did not convert morphine into a MOR internalizing agent in HEK293 cells. $A$, Percentage loss of surface MOR expression after various periods of opioid exposure $\left({ }^{*} p<\right.$ 0.05 morphine vs DAMG0 or methadone; $n=5-13)$. $B$, Coapplication of DAMGO (10 nm) did not enhance $5 \mu \mathrm{m}$ morphine-induced MOR loss $(n=7)$. Coapplication of $100 \mathrm{~nm} \mathrm{DAMG0}$ and $5 \mu \mathrm{M}$ morphine ( $C$ or $500 \mathrm{~nm}$ DAMG0 and $30 \mu \mathrm{m}$ morphine (D) did not significantly increase receptor loss compared with morphine alone. Although the mean percentage receptor loss in each case with DAMGO and morphine was greater compared with morphine alone, this effect was not statistically significant and was lower than the mean receptor loss with DAMGO alone ( $n=$ 5-6). $E$, In HEK293 cells with high MOR expression levels, 100 nм DAMG0 and $5 \mu \mathrm{m}$ morphine either alone or combined caused negligible receptor loss $(n=4)$.

nificantly less receptor loss than methadone $(30 \mu \mathrm{M})$ or DAMGO $(10 \mu \mathrm{M})$ (Fig. 3A). We then sought to determine the effect of a low concentration of DAMGO on morphine-induced receptor loss but failed to observe a significant increase in receptor loss when DAMGO (100 nM) and morphine $(5 \mu \mathrm{M})$ were coapplied compared with morphine $(5 \mu \mathrm{M})$ alone (Fig. $3 C)$. Although the mean receptor loss was increased (from $10.1 \pm 3.6$ to $16.9 \pm 4.1 \%$; $n=$ $6)$ this effect was not statistically significant $(p>0.1)$ and, in-

deed, was less than that induced by $100 \mathrm{~nm}$ DAMGO alone $(25.0 \pm 6.4 \% ; n=6)$. DAMGO at $100 \mathrm{~nm}$ alone caused significant internalization, a finding that parallels the desensitization observed in rat LC neurons. We found that DAMGO, at $100 \mathrm{~nm}$, the concentration used by $\mathrm{He}$ et al. (2002), caused significant MOR internalization. We therefore repeated the experiment using 10 nM DAMGO, a concentration that produced negligible internalization, and found that coadministration with $5 \mu \mathrm{M}$ morphine did not increase MOR internalization when compared with morphine alone (Fig. $3 B$ ). We then repeated the experiments using a receptor-saturating concentration of morphine $(30 \mu \mathrm{M})$ but failed to see any enhancing effects of DAMGO (500 nM) on morphine-induced receptor loss (Fig. 3D).

To determine whether the level of receptor expression influenced our ability to observe an interaction between DAMGO and morphine, we also used an HEK293-MOR1 cell line expressing the MOR1 receptor at much higher levels $(1627 \pm 41 \mathrm{fmol} / \mathrm{mg}$ tissue). Although we saw equivalent receptor loss after $30 \mathrm{~min}$ incubation with $10 \mu \mathrm{M}$ DAMGO $(32.1 \pm 3.9 \%$; $n=8)$, we saw minimal receptor loss with $100 \mathrm{~nm}$ DAMGO. In addition, receptor loss induced by $5 \mu \mathrm{M}$ morphine was not increased by coadministration of morphine and $100 \mathrm{~nm}$ DAMGO (Fig. 3E).

Finally, we sought to determine whether the interaction between DAMGO and morphine could be observed on the MOR1B splice variant of the MOR1 receptor that has been shown to exhibit a different internalization profile to MOR1 (Koch et al., 1998). We repeated the experiments on HEK293 cells stably expressing the T7-epitope-tagged MOR1B splice variant (expression level, $490.3 \pm 54.3 \mathrm{fmol} / \mathrm{mg}$ ). Consistent with our data on MOR1, 100 nM DAMGO did not have an enhancing effect on 5 $\mu \mathrm{M}$ morphine-induced MOR1B receptor loss. After $30 \mathrm{~min}$ exposure to the drugs, receptor loss was $30.6 \pm 4.6 \%$ for DAMGO, $3.3 \pm 6.4 \%$ for morphine, and $13.7 \pm 5.5 \%$ for DAMGO plus morphine $(n=5)$.

\section{Discussion}

The data presented here demonstrate that, although methadone and morphine have near equivalent agonist efficacy at MORs, only methadone induced MOR desensitization in mature rat LC neurons and MOR internalization in HEK293 cells. We also found no evidence for low concentrations of the high-efficacy MOR agonist DAMGO increasing morphine-induced desensitization or internalization.

\section{Morphine is a weak receptor desensitizing and internalizing agent}

Desensitization and internalization of G-protein-coupled receptors have long been considered as direct consequences of receptor activation. Therefore, for a given level of receptor occupancy, desensitization and internalization should correlate with agonist efficacy. Whistler et al. (1999) challenged this view by reporting that morphine did not induce MOR desensitization and internalization, whereas methadone, which they reported to have lower efficacy than morphine, did induce desensitization and internalization. The literature, surprisingly, provides no consensus view on the relative agonist efficacy of morphine and methadone. Some studies report methadone as having greater efficacy than morphine (Ivarsson and Neil, 1989; Borgland et al., 2003), whereas others report it has equal (Selley et al., 1998) or lower efficacy (Yu et al., 1997; Whistler et al., 1999). In the current study, we first determined the relative efficacy of methadone and morphine to evoke GIRK (G-protein-gated inwardly rectifying $\mathrm{K}^{+}$channel) currents in LC neurons by comparing the maxi- 
mum responses to these partial agonists. We found these drugs to have very similar agonist efficacy. Methadone, but not morphine, induces MOR desensitization in mature rat LC neurons and HEK293 cells (Whistler et al., 1999; Alvarez et al., 2002; present work) and MOR internalization in AtT20 and HEK293 cells (Whistler et al., 1999; Alvarez et al., 2002; Borgland et al., 2003). Because this does not appear to be a consequence of relative efficacy, some other property of opioid agonists must determine the inability of morphine to induce internalization (Whistler et al., 1999).

There is however still some confusion about the ability of morphine to induce desensitization because other workers have reported morphine-induced rapid desensitization in AtT20 cells (Borgland et al., 2003). In AtT20 cells expressing murine MOR, morphine had lower efficacy than methadone and caused robust MOR desensitization but did not induce MOR internalization. The discrepancy between these results and those described above could result from species differences between the MORs studied or from differences in the desensitization mechanisms operating in different cell types. Differences in relative agonist efficacies between mouse and rat MORs (Yoburn et al., 1991; Selley et al., 1997) and DORs (Shimohigashi et al., 1987; Yoburn et al., 1991) have been reported previously.

In our experiments on LC neurons and HEK293 cells, morphine was not ineffective at inducing desensitization and internalization; rather, it induced much less MOR desensitization and internalization than methadone or DAMGO. Recently, Haberstock-Debic et al. (2003), studying nucleus accumbens neurons, have reported that morphine does not cause MOR internalization in neuronal somata but does induce MOR internalization in dendritic processes of the same neurons. Unfortunately, with the whole-cell patch-clamp technique, we were unable to determine whether the small amount of morphineinduced desensitization in LC neurons occurred at receptors on the dendrites.

\section{DAMGO does not convert morphine into a desensitizing and internalizing agent}

Although morphine is only a weak desensitizing agent, chronic morphine treatment in vivo produces both tolerance and dependence. Finn and Whistler (2001) proposed that it was precisely because morphine-activated MORs do not desensitize that tolerance to morphine develops, in that prolonged receptor activation by morphine may induce other cellular adaptive changes that result in the subsequent development of tolerance. Therefore, if morphine could be manipulated into a desensitizing agent, the ability of it to induce tolerance and dependence would be reduced. In an additional study, the same group went on to report that, by combining a low concentration of DAMGO with morphine, MOR internalization was facilitated and tolerance to morphine-induced analgesia attenuated (He et al., 2002).

In our study, however, we found no evidence for an interaction between DAMGO and morphine at the level of MOR desensitization in either LC or myenteric neurons or at the level of MOR internalization in HEK293 cells. Indeed, we observed the opposite in that the desensitization in LC neurons induced by low concentrations of DAMGO (seen even at a concentration as low as $100 \mathrm{~nm}$ ) was in fact reduced by the presence of morphine. The reasons why we failed to see an enhancement of morphineinduced desensitization and internalization by DAMGO are unclear. By studying the development of both MOR desensitization and internalization, we ruled out the possibility that the interaction occurs only at the level of one of these interrelated phenom- ena. We also failed to observe any interaction on endogenously expressed neuronal receptors as well as on receptors expressed both at low and at high levels in HEK293 cells.

There are several splice variants of the MOR receptor that exhibit different desensitization and internalization profiles (Koch et al., 1998; Abbadie and Pasternak, 2001). Rat LC neurons have been reported to express the MOR1 receptor (Schulz et al., 1998; Abbadie et al., 2000a,b). However, in the internalization experiments in HEK293 cells, we studied both MOR1 and MOR1B receptors and still found no evidence for an interaction between morphine and DAMGO. Given that the MOR1C splice variant internalizes during exposure to morphine alone (Abbadie and Pasternak, 2001), it is unlikely that DAMGO could reveal morphine-induced desensitization by an interaction with this splice variant.

There is considerable evidence from coimmunoprecipitation experiments that MORs exist as homomeric oligomers (George et al., 2000; Gomes et al., 2002; He et al., 2002). He et al. (2002) interpreted their observation of increased morphine-induced MOR internalization by low concentrations of DAMGO as functional evidence for such oligomerization. Our inability to observe any enhanced MOR desensitization or internalization means that the functional significance of MOR oligomerization remains to be elucidated.

In conclusion, the data presented here show that morphine, unlike methadone or DAMGO, produces very little MOR desensitization or internalization, an effect not directly correlated with efficacy. Furthermore, we have been unable to find evidence for low concentrations of DAMGO increasing morphine-induced desensitization or internalization in LC neurons, myenteric neurons, or HEK293 cells.

\section{References}

Abbadie C, Pasternak GW (2001) Differential in vivo internalization of MOR-1 and MOR-1C by morphine. NeuroReport 12:3069-3072.

Abbadie C, Pan YX, Pasternak GW (2000a) Differential distribution in rat brain of mu opioid receptor carboxy terminal splice variants MOR-1Clike and MOR-1-like immunoreactivity: evidence for region-specific processing. J Comp Neurol 419:244-256.

Abbadie C, Pan Y, Drake CT, Pasternak GW (2000b) Comparative immunohistochemical distributions of carboxy terminus epitopes from the mu-opioid receptor splice variants MOR-1D, MOR-1 and MOR-1C in the mouse and rat CNS. Neuroscience 100:141-153.

Alvarez VA, Arttamangkul S, Dang V, Salem A, Whistler JL, von Zastrow M, Grandy DK, Williams JT (2002) $\mu$-Opioid receptor: ligand-dependent activation of potassium conductance, desensitization, and internalization. J Neurosci 22:5769-5776.

Arden JR, Segredo V, Wang Z, Lameh J, Sadee W (1995) Phosphorylation and agonist-specific intracellular trafficking of an epitope-tagged $\mu$-opioid receptor expressed in HEK293 cells. J Neurochem 65:1636-1645.

Borgland SL, Connor M, Osborne PB, Furness JB, Christie MJ (2003) Opioid agonists have different efficacy profiles for G-Protein activation, rapid desensitization, and endocytosis of mu-opioid receptors. J Biol Chem 278:18776-18784.

Daunt DA, Hurt C, Hein L, Kallio J, Feng F, Kobilka BK (1997) Subtypespecific intracellular trafficking of $\alpha 2$-adrenergic receptors. Mol Pharmacol 51:711-720.

Finn AK, Whistler JL (2001) Endocytosis of the mu-opioid receptor reduces tolerance and a cellular hallmark of opiate withdrawal. Neuron 32:829-839.

George SR, Fan T, Xie Z, Tse R, Tam V, Varghese G, O’Dowd BF (2000) Oligomerization of mu- and delta-opioid receptors. Generation of novel functional properties. J Biol Chem 275:26128-26135.

Gomes I, Filipovska J, Jordan BA, Devi LA (2002) Oligomerization of opioid receptors. Methods 27:358-365.

Haberstock-Debic H, Wein M, Barrot M, Colago EE, Rahman Z, Neve RL, Pickel VM, Nestler EJ, von Zastrow M, Svingos AL (2003) Morphine acutely regulates opioid receptor trafficking selectively in dendrites of nucleus accumbens neurons. J Neurosci 23:4324-4332. 
He L, Fong J, von Zastrow M, Whistler JL (2002) Regulation of opioid receptor trafficking and morphine tolerance by receptor oligomerization. Cell 108:271-282.

Ishimatsu M, Williams JT (1996) Synchronous activity in locus coeruleus results from dendritic interactions in pericoerulear regions. J Neurosci 16:5196-5204.

Ivarsson M, Neil A (1989) Differences in efficacies between morphine and methadone demonstrated in the guinea pig ileum: a possible explanation for previous observations on incomplete cross-tolerance. Pharmacol Toxicol 65:368-371.

Keith DE, Murray SR, Zaki PA, Chu PC, Lissin DV, Kang L, Evans CJ, von Zastrow M (1996) Morphine activates opioid receptors without causing their rapid internalization. J Biol Chem 271:19021-19024.

Koch T, Schulz S, Schroder H, Wolf R, Raulf E, Hollt V (1998) Carboxylterminal splicing of the rat mu opioid receptor modulates agonistmediated internalization and receptor resensitization. J Biol Chem 273:13652-13657.

Kosterlitz HW, Lydon RJ, Watt AJ (1970) The effect of adrenaline, noradrenaline and isoprenaline on inhibitory $\alpha$ and $\beta$ receptors in the longitudinal muscle of the guinea-pig ileum. Br J Pharmacol 14:209-214.

Pepper CM, Henderson G (1980) Opiates and opioid peptides hyperpolarize locus coeruleus neurons in vitro. Science 209:394-395.

Schulz S, Schreff M, Koch T, Zimprich A, Gramsch C, Elde R, Hollt V (1998) Immunolocalization of two mu-opioid receptor isoforms (MOR1 and MOR1B) in the rat central nervous system. Neuroscience 82:613-622.
Selley DE, Sim LJ, Xiao R, Liu Q, Childers SR (1997) $\mu$-Opioid receptorstimulated guanosine-5'-O-( $\gamma$-thio)-triphosphate binding in rat thalamus and cultured cell lines: signal transduction mechanisms underlying agonist efficacy. Mol Pharmacol 51:87-96.

Selley DE, Liu Q, Childers SR (1998) Signal transduction correlates of muopioid agonist intrinsic efficacy: receptor-stimulated $\left[{ }^{35} \mathrm{~S}\right] \mathrm{GTP} \gamma \mathrm{S}$ binding in $\mu \mathrm{MOR}-\mathrm{CHO}$ cells and rat thalamus. J Pharmacol Exp Ther 285:496-505.

Shimohigashi Y, Costa T, Pfeiffer A, Herz A, Kimura H, Stammer CH (1987) delta Ephe4-enkephalin analogs. Delta receptors in rat brain are different from those in mouse vas deferens. FEBS Lett 222:71-74.

Tempel A, Zukin RS (1987) Neuroanatomical patterns of the $\mu, \delta$ and $\kappa$-opioid receptors of rat brain as determined by quantitative in vitro autoradiography. Proc Natl Acad Sci USA 84:4308-4312.

Whistler JL, Chuang HH, Chu P, Jan LY, von Zastrow M (1999) Functional dissociation of $\mu$-opioid receptor signalling and endocytosis: implications for the biology of opiate tolerance and addiction. Neuron 23:737-746.

Yoburn BC, Lufty K, Candido J (1991) Species differences in mu- and deltaopioid receptors. Eur J Pharmacol 193:105-108.

Yu Y, Zhang L, Yin X, Sun H, Uhl GR, Wang JB (1997) $\mu$-Opioid receptor Phosphorylation, desensitization, and ligand efficacy. J Biol Chem 272: 28869-28874. 